\title{
Tick (Acari: Ixodidae) infestation of cuscuses from Maluku Province, Indonesia
}

\author{
Prasetyarti Utami ${ }^{1,2}$ (D), Bambang Heru Budianto ${ }^{1}$ (i) and Ana Sahara ${ }^{3}$ (D) \\ 1. Faculty of Biology, Universitas Jenderal Soedirman, Purwokerto, Central Java, Indonesia; 2. Program of Biology, \\ Faculty of Science and Technology, Universitas Terbuka, Jakarta, Indonesia; 3. Department of Parasitology, Faculty of \\ Veterinary Medicine, Universitas Gadjah Mada, Yogyakarta, Indonesia. \\ Corresponding author: Ana Sahara, e-mail: sahara@ugm.ac.id \\ Co-authors: PU: prasetyarti@ut.ac.id, BHB: bambang.budianto@unsoed.ac.id \\ Received: 03-01-2021, Accepted: 08-04-2021, Published online: 08-06-2021
}

doi: www.doi.org/10.14202/vetworld.2021.1465-1471 How to cite this article: Utami P, Budianto BH, Sahara A (2021) Tick (Acari: Ixodidae) infestation of cuscuses from Maluku Province, Indonesia, Veterinary World, 14(6): 1465-1471.

\begin{abstract}
Background and Aim: Cuscuses are one of the endemic Indonesian marsupials, which needs to be protected and revived in terms of the numbers and range of species. Ectoparasites of ticks (Ixodidae) are one potential obstacle to cuscus conservation. Tick infestation can cause blood loss in the host, even being a predisposing factor for infection with pathogenic organisms. This study aimed to determine the prevalence, infestation intensity, and species of ticks present on cuscuses in Maluku Province, Indonesia.

Materials and Methods: Ticks were collected from cuscuses origin of the four regions in Maluku Province, namely the island of Ambon, Seram Island, Romang Island, and Wetar Island. Cuscuses were captured at night, with ticks being collected from them from the head to the tip of the tail. The tick samples obtained from the cuscuses were preserved, identified, and counted. Cuscuses were released back into their habitat after collecting the ticks. The obtained ticks were observed using an Olympus BX51 microscope with an Olympus DP12 digital camera and prepared for examination under a scanning electron microscope (SEM). Infestation rate, infestation intensity, and morphology of the species were described.

Results: The cuscuses were found to be infested with Ixodes cordifer ticks. Cuscuses in Maluku Province had a low tick infestation rate. The range of infestation prevalence of island origin cuscuses in Maluku was between $14.28 \%$ and $16.67 \%$. Simultaneously, I. cordifer infestation level was mildly infested based on the intensity of thick infestation ranged from 1 to 1.2 ticks per cuscus. From observation of the tick surface structure under SEM, sexual dimorphism and various specific characteristics of the ticks were identified.

Conclusion: The low infestation rate of I. cordifer ticks in cuscus was influenced by the up and down movement of the conscious activity in the tree, which allowed minimal contact with the ticks. The infestation prevalence rates on each island studied were similar. Such similarities of infestation are related to the similarity of cuscus species among Ambon, Lakor, Seram, and Romang islands, which are all included in the Phalangeridae family, and their similar habitats, behaviors, climatic conditions, and geographical areas.
\end{abstract}

Keywords: Cuscus, Ixodes, scanning electron microscope.

\section{Introduction}

Cuscus is a marsupial of the Phalangeridae family with a relatively wide distribution, which is especially prevalent in East Indonesia and Papua New Guinea. The distribution of cuscus in Indonesia is restricted to the east of the country, in Maluku, Sulawesi, Papua, and Timor [1]. Several species of cuscus are critically endangered and headed for extinction (vulnerable), such as woodlark cuscus (Phalanger lullulae), Gebe cuscus (Phalanger alexander), blue-eyed spotted cuscus (Spilocuscus wilsoni), Telefomin cuscus (Phalanger matanim), black-spotted cuscus (Spilocuscus rufoniger), Talaud bear cuscus (Ailurops melanotis), Waigeo cuscus

Copyright: Utami, et al. Open Access. This article is distributed under the terms of the Creative Commons Attribution 4.0 International License (http://creativecommons.org/licenses/by/4.0/), which permits unrestricted use, distribution, and reproduction in any medium, provided you give appropriate credit to the original author(s) and the source, provide a link to the Creative Commons license, and indicate if changes were made. The Creative Commons Public Domain Dedication waiver (http://creativecommons.org/ publicdomain/zero/1.0/) applies to the data made available in this article, unless otherwise stated.
(Spilocuscus papuensis), bear cuscus (Ailurops ursinus), and blue-eyed cuscus (Phalanger matabiru). There are six cuscus genera globally, namely, Ailurops, Phalanger, Spilocuscus, Strigocuscus, Wyulda, and Trichosurus, with 28 species [2]. Four genera of the Phalangeridae are distributed in Indonesia, with several species endemic to Papua, the Maluku Islands, and the Sulawesi Islands There are approximately 24 species of cuscus in Indonesia, but they are becoming increasingly rare. Flannery [3] reported that Phalanger orientalis was scattered from Timor, Wetar, the Maluku Islands of Misool, Batanta, Salawati, and New Guinea to the Bismarck islands on the eastern side of Papua New Guinea.

Spilocuscus spp. have been reported to be scattered in the southern part of the Maluku Islands (Buru, Seram, Banda, and Ambon), Aru Islands, Kei Islands, Misool, Yapen, and the mainland of New Guinea (Papua), as well as to inhabit a small part of Cape York Peninsula in North Australia [4].

In Indonesia, cuscus has been protected since 1979 by the prohibition on the capture of such animals, 
as set out in the Order Minister of Agriculture No. 247/ KPTS/UM4/1979, Wild Animal Hunting Regulation (PPBL) No. 226/1931, Law No. 5/1990 concerning the conservation of living natural resources and their ecosystems, and Law No. 7/1999 concerning the preservation of plant and animal species. According to CITES data (Convention on International Trade in Endangered Species of Wild Fauna and Flora), several Indonesian marsupial species are endangered, so they are included in Appendix II, while IUCN data (International Union for Conservation of Nature and Natural Resources) classify them as endangered species (IUCN, 2008). Kunda et al. [5,6] stated that the decline in the cuscus population has been significantly influenced by hunting by humans, while genetic factors have also contributed. Illegal hunting is the basis for trading in its illegal meat, as it is consumed as a protein source and to meet meat needs during church ceremonies $[7,8]$.

Pathologically, all members of marsupials are susceptible to pathogenic infections by bacteria, viruses, or parasites [9]. Ticks can cause health problems such as anemia, dermatitis, and secondary infections [10]. The ectoparasites found in almost all groups of marsupials are hard ticks belonging to the genus Ixodes. Ticks of the genus Ixodes Latreille, 1795 , are common parasites of reptiles, birds, and mammals worldwide. The tick species Ixodes cordifer has been found in cuscuses in Indonesia [11,12], but the infestation rate and intensity of tick infestation have not been reported. There is also a need to describe the surface ultrastructural morphology of the ticks because no study has been carried out on ticks obtained from cuscuses in Indonesia.

This study aimed to determine the prevalence, infestation intensity, and species of ticks present on cuscuses in Maluku Province, Indonesia. There is also a need to compare detailed morphological features of the ticks with the descriptions that have been reported previously.

\section{Materials and Methods}

\section{Ethical approval}

This study is complementary to the ethical requirements of laboratory animals and has been approved by the Ethics Committee team of Laboratorium Penelitian dan Pengujian Terpadu Universitas Gadjah Mada (LPPT UGM).

\section{Study period and location}

This research was conducted from August 2017 to July 2020. Collection of ticks on cuscus was carried out in Maluku Province namely Ambon Island, Seram Island, Romang Island, and Wetar Island (Figure-1). Samples were processed at Indonesian Institute of Sciences, Cibinong, Indonesia; Laboratorium Penelitian dan Penujuan Terpadu, Universitas Gadjah Mada (LPPT UGM); and Laboratory of Parasitology, Faculty of Veterinary Medicine, Universitas Gadjah Mada, Yogyakarta, Indonesia.

\section{Tick collection}

Cuscuses were captured using a method involving imitation of their sounds to lure them out of the undergrowth. This is a well-recognized approach locally. When a cuscus jumped from one branch to another and reached the point where the sounds originated, it was

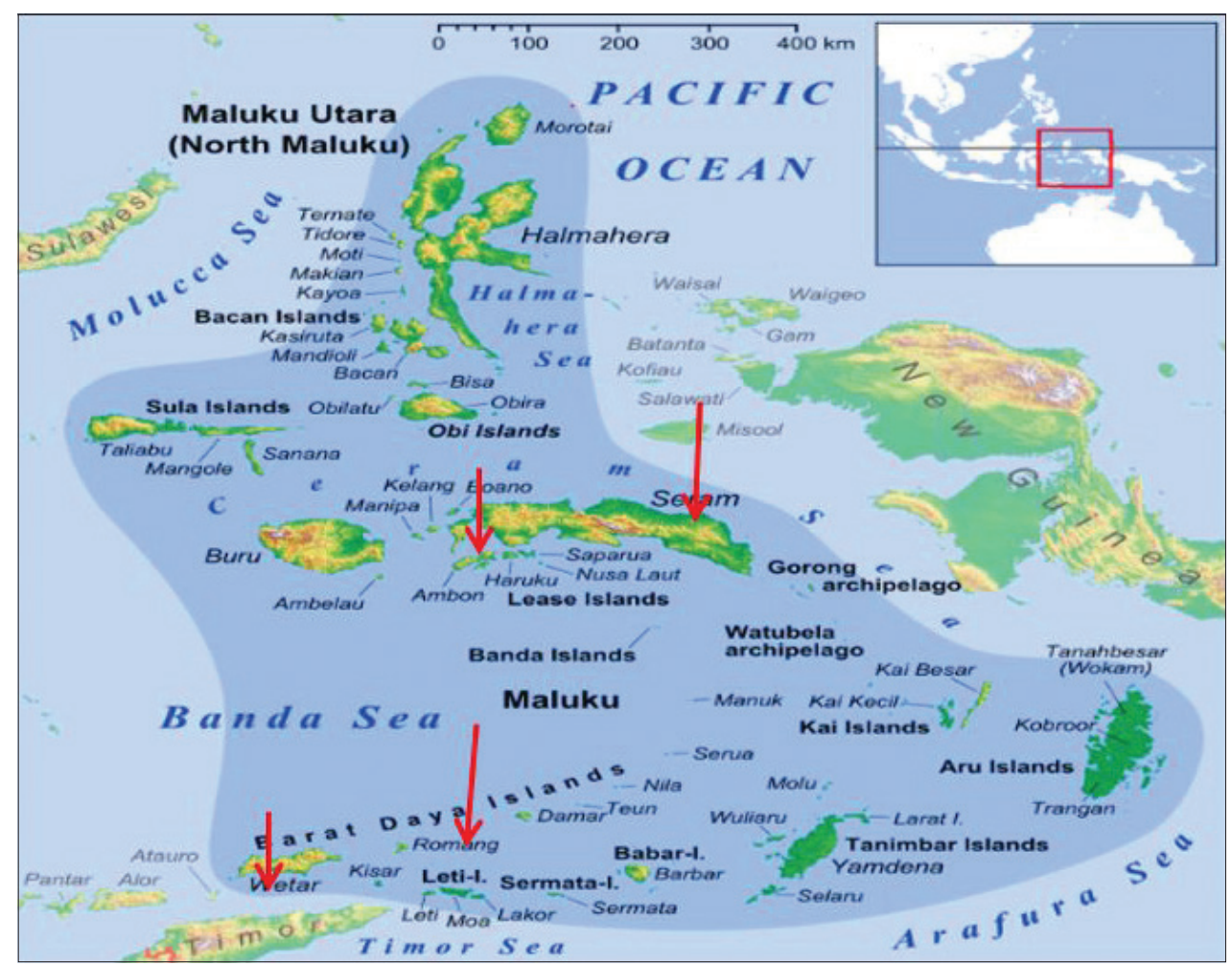

Figure-1: Locations of tick collection on cuscus on Wetar, Romang, Ambon, and Seram Islands (Source: https:// id.wikipedia.org/wiki/Kepulauan_Maluku). 
captured with a gunny sack and immediately injected with ketamine and xylazine by veterinary personnel. In an unconscious state, each captured cuscus was carefully examined for ticks (Figure-2). Subsequently, the cuscus was allowed to return to consciousness and injected with $0.5 \mathrm{ml}$ of Vitamin B complex, after which it could return to its habitat. The ticks obtained from the cuscuses were prepared on slides and examined by scanning electron microscopy (SEM).

\section{Morphological identification}

The morphological characteristics of the ticks were observed with an Olympus BX51 microscope and an Olympus DP12 digital camera. Ultrastructural observation was performed by SEM with a JEOL JSM-651OLA. The observed features included overall appearance, and anterior and posterior parts. SEM preparations were performed through Integrated Research and Testing Laboratory Gadjah Mada University procedures. Identification was performed based on morphological features using an identification key [13-16].

\section{Statistical analysis}

The structure of the ticks was analyzed descriptively according to existing references. The level of tick infestation was categorized according to the intensity of the ticks. When between 1 and 25 ticks were found on one cuscus, this was categorized as mild infestation, between 26 and 50 as moderate infestation, and 51 or more as severe infestation [17]. The prevalence of tick infestation and its intensity was calculated in accordance with a previous report [18].

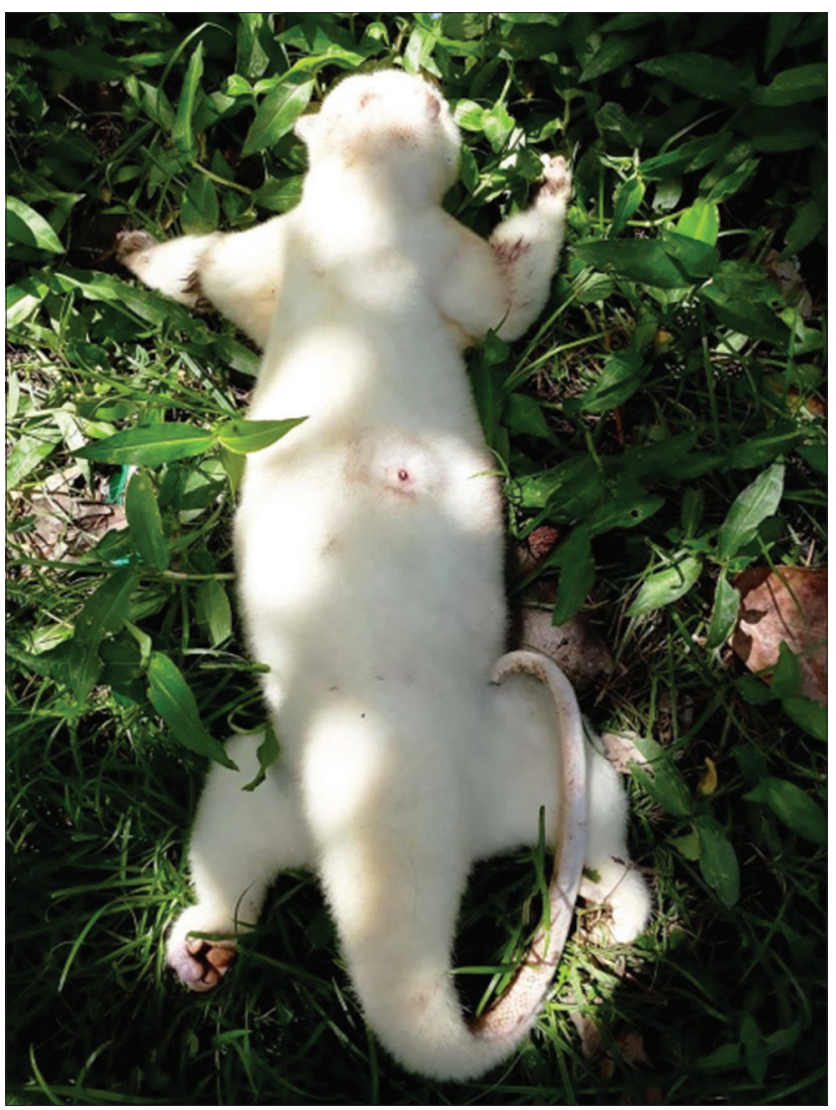

Figure-2: Cuscus caught and anesthetized.
The determined prevalence of tick-infested cuscuses is presented as the proportion of cuscuses infected with tick relative to the total number of cuscus samples. The intensity of tick infestation was determined based on comparison between the average number of individual ectoparasite species and the number of infested cuscuses.

\section{Results}

The ticks collected from cuscuses from Ambon, Wetar, Romang, and Seram were morphologically examined microscopically and identified as members of the genus Ixodes through the presence of a distinct anal groove anterior of the anus. The Ixodes ticks were in the subgenus Sternalixodes [16,19]. One of the characteristics of this subgenus is the presence of a sternal plate on the ventral part of the body. The morphology of male and female I. cordifer is shown in Figure-3. The genital aperture was situated at the level between coxae I and II in males and at the mid-fourth intercostal space in females. Male I. cordifer was first described by Neumann [13]. Male I. cordifer from Maluku has an elongated oval body, with a glossy scutum covering the entire dorsum. The male body is brownish-yellow and dark. All males have legs of the same brown color. The palps are relatively short and wide, but narrower than the basis capituli.

The males were found to be moderate in size, with a body length of 2.6-2.95 mm and width of 1.861$1.931 \mathrm{~mm}$, and a capitulum length of $0.34-0.42 \mathrm{~mm}$ and width of $0.32-0.4 \mathrm{~mm}$ (Table-1). Palpal article 1 is transverse, while palpal articles 2-3 are fused and then narrow. The male ticks' hypostome is characterized by two short and blunt teeth (Figure-4). The scutum has a linear lateral carina; the punctuation size is small and sparse distribution on conscutum. The male ticks have two spurs on coxae 1-3, with the internal spurs being inconspicuous while the spurs on coxa 4 are single and pointed. There are short lateral carinae with tapered scapulae. The base of the capituli is pentagonal in shape, the dorsal part does not have cornua and does not have auricula on the ventral side. I. cordifer has scattered, fine, and short hair. The median plate is broad and quadrangular in shape. The pregenital plate is located on coxa 2 and has an adanal plate. The anal groove joins toward the posterior. The anal plate is heart shaped and tapers in males.

Female I. cordifer is $3.15-10.5 \mathrm{~mm}$ in length and 1.9-8.8 $\mathrm{mm}$ in width (Table-1), idiosoma ovoid widest at the posterior end of the scutum. The capitulum in female ticks is longer than that in males. The hypostome of female ticks is characterized by elongated and sharp teeth lanceolate. The base of the capituli does not have a cornua and has a separate porous area. Punctuations on the scutum are dense and small at the posterior. The morphology of the tick is more clearly visible on the scanning electron microscopy figure. Female ticks have a 3:3 tooth arrangement (Figure-5). The lateral part of the carina is well

Veterinary World, EISSN: 2231-0916 


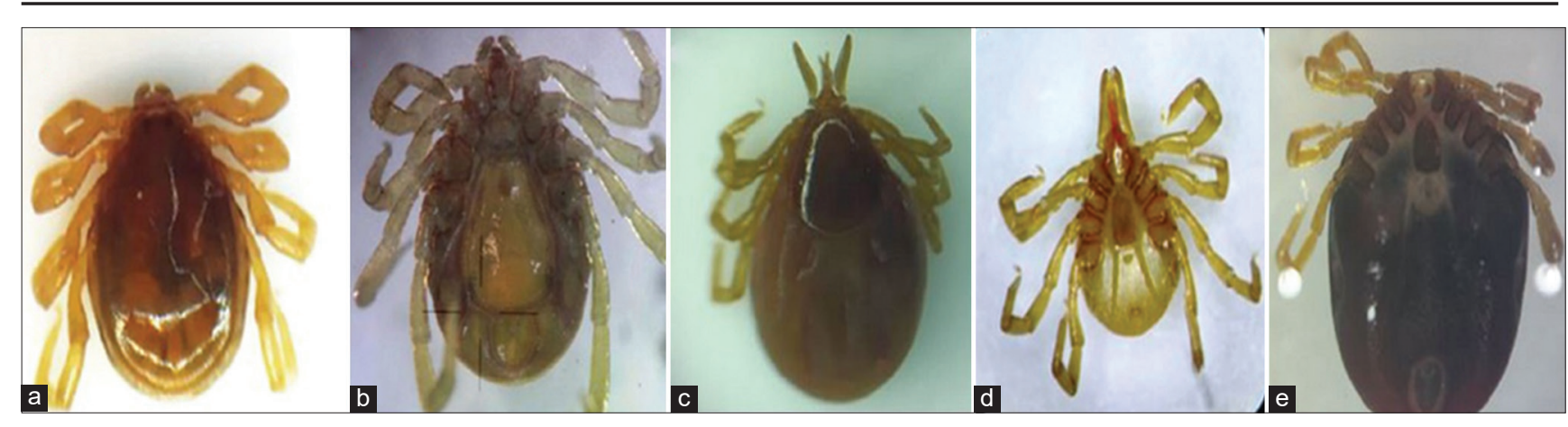

Figure-3: Morphology of Ixodes cordifer. (a) Dorsal (male); (b) ventral (male); (c) dorsal (female); (d) ventral (female); (e) ventral engorged (female). Magnification 20x.

Table-1: Morphometry of male and female Ixodes cordifer ( $\mathrm{mm})$.

\begin{tabular}{|c|c|c|c|c|c|c|c|c|}
\hline Location & BL & LG & LI & WI & LS & ws & LDCB & WDCB \\
\hline \multicolumn{9}{|l|}{ Ambon } \\
\hline $\mathrm{F}$ & 6.394 & 1.098 & 5.296 & 3.308 & 1.822 & 1.867 & 0.425 & 0.547 \\
\hline M & 2.95 & 0.347 & 2.603 & 1.861 & 2.55 & 1.861 & 0.2 & 0.328 \\
\hline $\mathrm{F}$ & 4.52 & 1.05 & 3.50 & 2.933 & 1.462 & 1.721 & 0.4 & 0.43 \\
\hline $\mathrm{F}$ & 3.99 & 0.94 & 3.05 & 2.35 & 1.420 & 1.690 & 0.38 & 0.42 \\
\hline \multicolumn{9}{|l|}{ Wetar } \\
\hline $\mathrm{F}$ & 3.115 & 0.954 & 2.161 & 2.02 & 1.877 & 1.910 & 0.41 & 0.472 \\
\hline $\mathrm{F}$ & 10.5 & 1.086 & 9.414 & 8.82 & 1.650 & 1.848 & 0.53 & 0.57 \\
\hline $\mathrm{F}$ & 3.15 & 0.92 & 2.23 & 1.91 & 1.850 & 1.930 & 0.39 & 0.42 \\
\hline $\mathrm{F}$ & 8.80 & 1.15 & 7.65 & 6.90 & 1.890 & 1.960 & 0.5 & 0.54 \\
\hline $\mathrm{F}$ & 7.75 & 1.080 & 6.67 & 5.70 & 1.852 & 1.882 & 0.52 & 0.56 \\
\hline \multicolumn{9}{|l|}{ Seram } \\
\hline M & 2.625 & 0.421 & 2.204 & 1.931 & 2.125 & 1.931 & 0.30 & 0.407 \\
\hline $\mathrm{F}$ & 7.63 & 1.080 & 6.55 & 5.550 & 1.820 & 1.925 & 0.384 & 0.415 \\
\hline $\mathrm{F}$ & 8.71 & 1.12 & 7.59 & 6.772 & 1.874 & 1.954 & 0.47 & 0.53 \\
\hline $\mathrm{F}$ & 7.56 & 1.08 & 6.48 & 5.82 & 1.877 & 1.901 & 0.47 & 0.49 \\
\hline $\mathrm{F}$ & 6.85 & 1.07 & 5.78 & 3.50 & 1.855 & 1.870 & 0.44 & 0.564 \\
\hline $\mathrm{F}$ & 7.44 & 1.08 & 6.36 & 5.56 & 1.860 & 1.895 & 0.47 & 0.57 \\
\hline \multicolumn{9}{|l|}{ Romang } \\
\hline $\mathrm{F}$ & 4.619 & 0.9 & 3.719 & 2.754 & 1.454 & 1.790 & 0.49 & 0.52 \\
\hline $\mathrm{F}$ & 4.55 & 0.9 & 3.650 & 2.963 & 1.436 & 1.762 & 0.473 & 0.482 \\
\hline $\mathrm{F}$ & 5.119 & 1.060 & 4.059 & 3.061 & 1.691 & 1.820 & 0.51 & 0.57 \\
\hline $\mathrm{F}$ & 4.650 & 0.988 & 3.662 & 2.967 & 1.540 & 1.785 & 0.48 & 0.5 \\
\hline $\mathrm{F}$ & 4.700 & 1.016 & 3.684 & 2.676 & 1.601 & 1.799 & 0.501 & 0.746 \\
\hline Average & 5.78 & 0.97 & 4.91 & 3.97 & 1.78 & 1.86 & 0.44 & 0.50 \\
\hline \multirow[t]{2}{*}{ SD } & 2.26 & 0.22 & 2.14 & 2.03 & 0.27 & 0.08 & 0.08 & 0.09 \\
\hline & $5.78 \pm 2.26$ & $0.97 \pm 0.22$ & $4.91 \pm 2.14$ & $3.97 \pm 2.03$ & $1.78 \pm 0.27$ & $1.86 \pm 0.08$ & $0.44 \pm 0.08$ & $0.504 \pm 0.09$ \\
\hline
\end{tabular}

F=Female, M=Male, BL=Body length, LG=Length of Gnathostoma, LI=Length of idiosoma, WI=Wide of idiosoma; $\mathrm{LS}=$ Length of scutum, WS =Wide of scutum, LDCB=Length of dorsal capitulum base, WDCB=Wide of dorsal capitulum base

developed, while the base of the capituli is pentagonal, having a slender elongated palpal with transverse palpal article 1 and fused palpal articles 2/3. Female ticks have a round scapula. The auricula in females was found at the ventral base of the capituli. This is consistent with a previous finding [16] that I. cordifer has auricula without cornua. The genital opening is located in coxa 4 , while the sternal plate is oval. The anal groove embraces the anus anteriorly, forming an arch and it is joined at the posterior to form a point. Coxae I-IV have external single spurs with a hilllike shape, while the spiracular plate is subcircular or broadly oval. The general shape of Haller's organ is oval to elliptical, along with an accessory pit with seven setae, not tightly clustered in the center, with two large setae and five small setae.
Cuscuses in Ambon, Wetar, Seram, and Romang had low rates of infestation with I. cordifer. The species of cuscus infested with the tick I. cordifer are Phalanger orientalis and Spilocuscus maculatus. Not all cuscuses found on the islands of Ambon, Wetar, Seram, and Romang were infested with ticks. I. cordifer was found on cuscuses at a low infestation rate as fewer than 25 ticks were found per animal on each island. Observations of $I$. cordifer ticks found in cuscuses from Maluku showed that the collected ticks had an average intensity of 1.06 The rates of I. cordifer infestation among cuscuses from islands in Maluku ranged between $14.28 \%$ and $16.67 \%$ (Table-2). Meanwhile, I. cordifer intensity in cuscuses from Maluku ranged from 1 to 1.2. The caught cuscuses were P. orientalis and P. maculatus, with ticks more commonly being found on the cuscus abdomen (Table-3). 


\section{Discussion}

In Indonesia, the genus Ixodes consists of only five species: I. granulatus, I. spinicoxalis, I. werneri, and I. kopsteini [14]. The first three species are

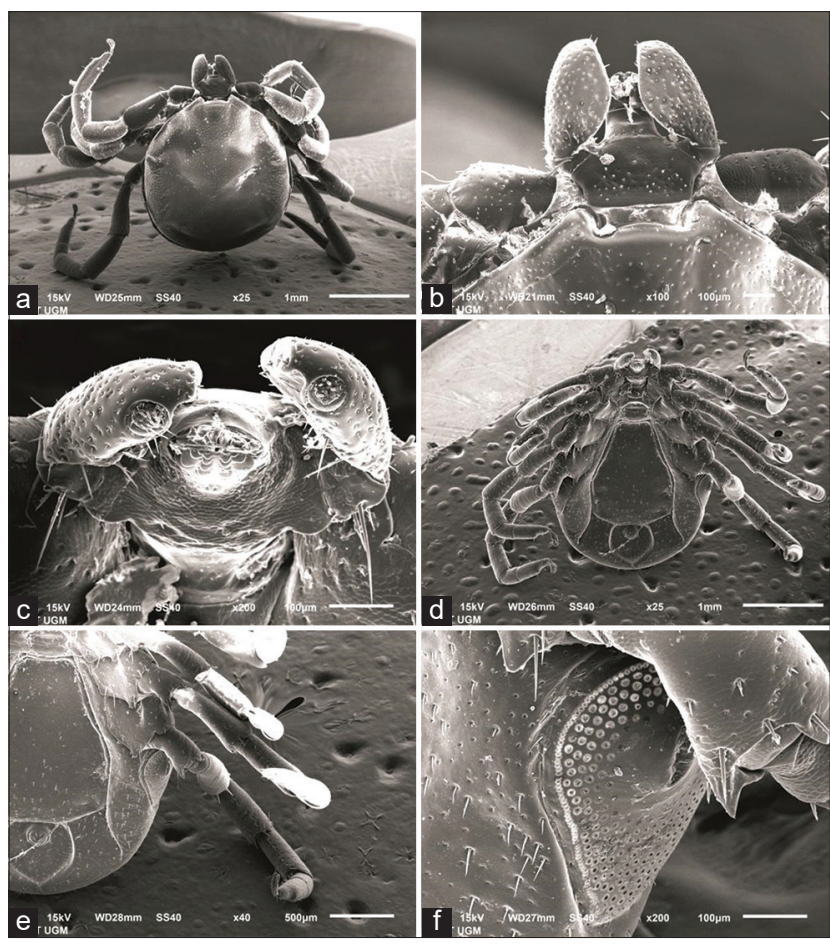

Figure-4: Scanning electron microscopy of Ixodes cordifer male. (a) Dorsal; (b) Gnathostoma; (c) dentition; (d) ventral; (e) coxae I-IV; (f) spiracle. Scale bars: (a) $1 \mathrm{~mm}$; (b and c) $100 \mu \mathrm{m}$; (d) $1 \mathrm{~mm}$; (e) $500 \mu \mathrm{m}$; (f) $100 \mu \mathrm{m}$. parasitic on rats, while the last is on bats. Two females Ixodes cordifer were found from cuscuses on Ambon Island [20]; later, the tick was found in the bear cuscus (Ailurops ursinus) at Sulawesi [11].

One individual male tick of I. cordifer was previously identified from Sekru (New Guinea), the western part of Irian Jaya [12], and successfully described [13], but its host was unknown. It was also previously reported [15] that several tick species from Papua were successfully identified as I. cordifer with Phalanger sp. as a host. However, reports on the tick I. cordifer [11-13] did not include a morphological description or detailed explanation. This limited amount of information is due to the difficulty of collecting samples and the rarity of ticks on cuscuses, as well as the biological activity of this marsupial.

This study identified as many as $20 \mathrm{I}$. cordifer, including 2 males and 18 females. These ticks were found on cuscuses on the islands of Ambon, Water, Seram, and Romang. The identified ticks were uniform in type. They were similarly distributed on these islands in Maluku, which is unsurprising given the similar environmental conditions, with similar supplies of resources and similar interactions between I. cordifer and its hosts.

There is clear sexual dimorphism of this tick species in the auricula. In males, no auricula was seen on the ventral side, which is consistent with a previous description of male $I$. cordifer [13]. In contrast, female $I$. cordifer has an auricula on the ventral side, with matched character matrics of Ixodes belonged to the subgenus
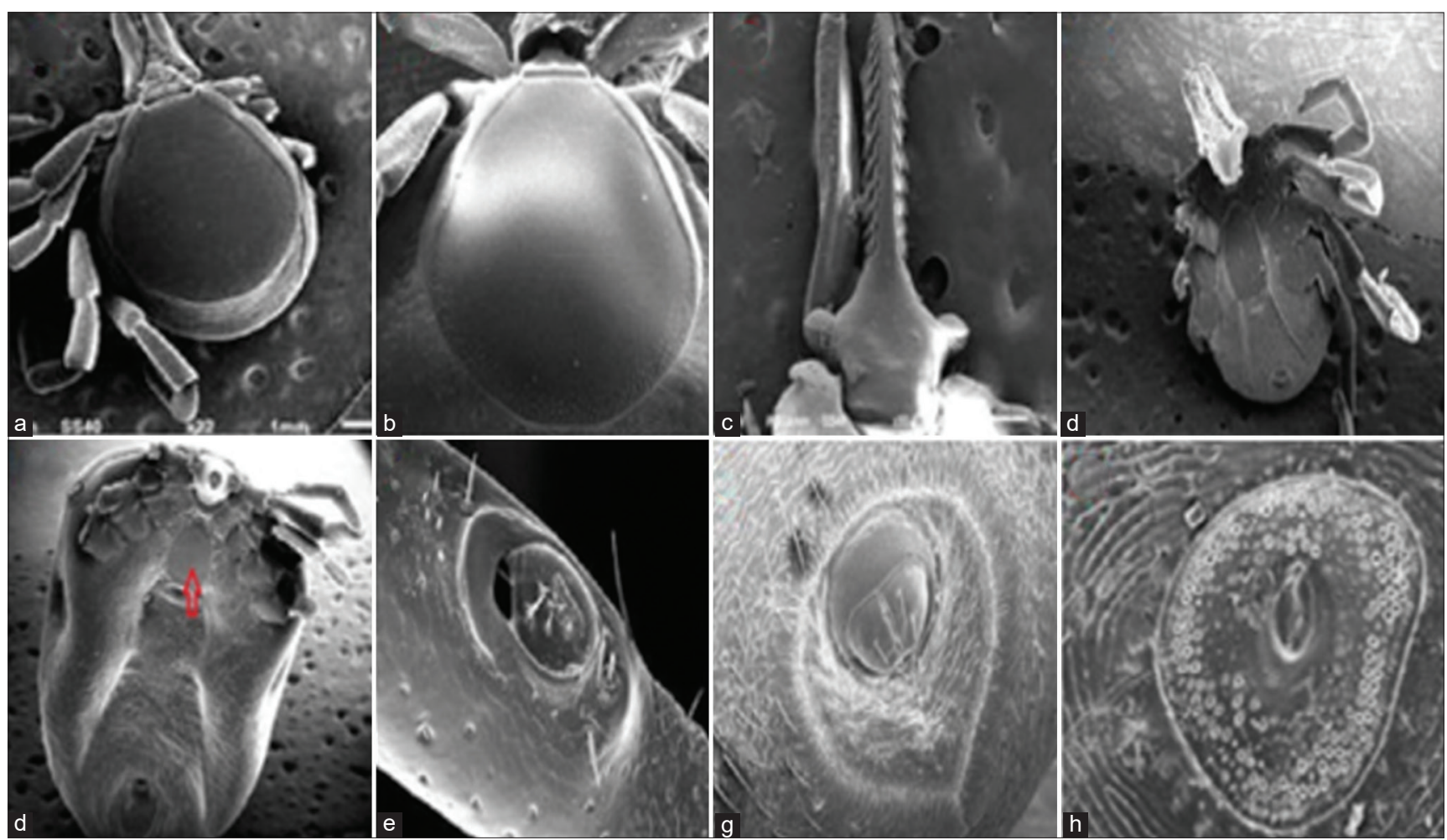

Figure-5: Scanning electron microscopy of Ixodes cordifer female from Maluku Province, Indonesia. (a) Dorsal; (b) scutum; (c) teeth arrangement of female; (d) ventral; (e) ventral of engorged; ( $f$ ) Haller's organ; ( $g$ ) anal; (h) spiraculum plate. Scale bars: (a) $1 \mu \mathrm{m}$; (b) $50 \mu \mathrm{m}$; (c) $200 \mu \mathrm{m}$; (d-f) $1 \mathrm{~mm}$; (g-h) $100 \mu \mathrm{m}$. Arrow: Sternal plate. 
Table-2: Prevalence and intensity of Ixodes cordifer on cuscus.

\begin{tabular}{|c|c|c|c|c|c|c|c|}
\hline No. & Region & Location & $\begin{array}{l}\text { Number } \\
\text { of cuscus }\end{array}$ & $\begin{array}{l}\text { Infested } \\
\text { cuscus }\end{array}$ & $\begin{array}{l}\text { Number Ixodes } \\
\text { cordifer collected }\end{array}$ & $\begin{array}{c}\text { Prevalence } \\
(\%)\end{array}$ & Intensity \\
\hline 1 & Ambon & Negeri Suli, Gunung Sahulutu & 25 & 4 & 4 & 16 & 1 \\
\hline 2 & Wetar & Desa Ustutun & 35 & 5 & 5 & 14.28 & 1 \\
\hline 3 & Seram & Outside Manusela National Park & 30 & 5 & 6 & 16.67 & 1,2 \\
\hline 4 & Romang & Desa Jerusu & $\begin{array}{c}35 \\
125\end{array}$ & $\begin{array}{c}5 \\
19\end{array}$ & $\begin{array}{c}5 \\
20\end{array}$ & 14.28 & 1 \\
\hline \multicolumn{3}{|c|}{ Average } & & & & $15.2 \%$ & 1.06 \\
\hline
\end{tabular}

Table-3: Region, cuscus species infested.

\begin{tabular}{|c|c|c|c|c|c|}
\hline No. & Island & Cuscus infested $I$. cordifer & Tick species & Attached on bodies & Number of tick \\
\hline \multirow[t]{4}{*}{1} & Ambon & P. orientalis (female) & I. cordifer (female) & Abdomen & 1 \\
\hline & & $P$. orientalis (male) & I. cordifer (female) & Abdomen & 1 \\
\hline & & P. orientalis (male) & I. cordifer (female) & Leg & 1 \\
\hline & & P. orientalis (male) & I. cordifer (male) & Abdomen & 1 \\
\hline \multirow[t]{5}{*}{2} & Wetar & P. orientalis (male) & I. cordifer (female) & Thorax & 1 \\
\hline & & P. orientalis (male) & I. cordifer (female) & Abdomen & 1 \\
\hline & & P. orientalis (male) & I. cordifer (female) & Abdomen & 1 \\
\hline & & P. orientalis (male) & I. cordifer (female) & Abdomen & 1 \\
\hline & & P. orientalis (male) & I. cordifer (female) & Thorax & 1 \\
\hline \multirow[t]{6}{*}{3} & Seram & S. maculatus (female) & I. cordifer (male) & Abdomen & 1 \\
\hline & & & I. cordifer (female) & Thorax & 1 \\
\hline & & P. orientalis (male) & I. cordifer (female) & Abdomen & 1 \\
\hline & & P. orientalis (male) & I. cordifer (female) & Abdomen & 1 \\
\hline & & P. orientalis (male) & I. cordifer (female) & Abdomen & 1 \\
\hline & & S. maculatus (male) & I. cordifer (female) & Thorax & 1 \\
\hline \multirow[t]{5}{*}{4} & Romang & P. orientalis (male) & I. cordifer (female) & Axilla & 1 \\
\hline & & P. orientalis (male) & I. cordifer (female) & Cervic & 1 \\
\hline & & P. orientalis (male) & I. cordifer (female) & Dorsum & 1 \\
\hline & & P. orientalis (male) & I. cordifer (female) & Abdomen & 1 \\
\hline & & P. orientalis (male) & I. cordifer (female) & Leg & 1 \\
\hline
\end{tabular}

I. cordifer=Ixodes cordifer, $P$. orientalis=Phalanger orientalis

Sternalixodes is largely present auricular [16]. The morphology of the spurs of coxae I-IV also differs between males and females. The male coxae I-III have two spurs (external and internal ones), with the internal spur not being conspicuous. Coxa IV has one external spur with a tapered shape and no internal spur.

In general, cuscuses hide in trees during the day, at the height of $15 \mathrm{~m}$ above the ground. They hide in tree holes and branches with dense canopy to avoid predators. The natural predators of cuscuses include several reptile species (e.g. snakes), but humans are now the main predators threatening the survival of these marsupials. During the day, this species generally hides in tree holes, tree crowns, and at night this species moves foraging by jumping from tree to tree to pick up fruit and seeds, where it possibly contacts larvae of $I$. cordifer. However, the results of this study prove that contact between cuscus and Ixodes occurs very rarely. Few Ixodes were found on cuscuses and they were extremely difficult to collect. This was also influenced by the season. Based on our observations, season is a significant determinant of the success or failure of Ixodes sp. to reach the host's (cuscus) body. During the dry season, Ixodes actually had difficulty finding cuscuses. However, Ixodes could be found in cuscuses during the rainy season. It is possible that, during the dry season, Ixodes could not withstand the heat and lacked water.
Thus, it might have made some adaptations by being active on vegetation close to the ground to save energy. It was previously suggested by Estrada Pena [21] that ticks were affected by season in a manner characterized by their upward and downward movement in vegetation. Cuscus behavior was also influenced by the growth of fruit during the dry season.

It was previously reported by Viggers et al. [22] that the I. trichosuri tick found in Trichosurus caninus marsupial from Cambarville, Australia, had an average intensity of 1.6, while I. tasmania had an average intensity of 1 . The intensity findings for Ixodes in Maluku resembled those for Australian marsupials. This shows that Ixodes ticks found in cuscuses and other marsupial groups are related to the hosts foraging or performing other activities at night, which determines the likelihood of contacting the tick.

The abdomen and the chest were chosen by I. cordifer as anatomical sites to attach themselves. The abdomen and the chest are the sites frequently in contact with trees when cuscuses look for food. Cuscuses were particularly likely to contact ticks when on trees looking for food. It was reported by Latif et al. [23] that predators such as rodents, birds, reptiles, ants, and pathogens such as fungi could limit the habitat of tick larvae when searching for a host. Birds, which were considered as a host of $I$. cordifer larvae, could possibly 
limit the ability of the tick $I$. cordifer to find cuscuses by bringing it outside of the cuscus's geographical range.

\section{Conclusion}

There is an external spur on the coxae of $I$. cordifer obtained from cuscuses in Maluku, where cuscuses have a low rate of $I$. cordifer infestation. This is probably due to the lack of opportunity for I. cordifer to encounter cuscuses and the difficulty of gathering samples of ticks on cuscuses given that they are arboreal and nocturnal animals. Infestations of $I$. cordifer ticks found in cuscuses from Maluku showed that the ticks that were collected had an average intensity of 1.06 . The average prevalence of $I$. cordifer-infested cuscuses from islands in Maluku was 15.2\%. The prevalence and intensity of infestation on each island examined were relatively similar. This would be due to the similar geographical and climatic conditions in Maluku.

\section{Authors' Contributions}

PU: Collected samples, analyzed the data, conducted research in the laboratory and wrote the manuscript. AS and BHB: Delivered reagents/materials/ analysis result, examined the data, wrote and critically revised the manuscript. All authors read and approved the final manuscript.

\section{Acknowledgments}

The authors would like to thank Directorate General of Higher Education, Ministry of Education and Culture Republic of Indonesia for funding this research (Grant no.: 10298/A2.1/KP/2018). The authors also thankful to Laboratory Staff from Indonesian Institute of Sciences, LPPT and UGM Staff supported the researchers in obtaining sample analysis results.

\section{Competing Interests} interests.

The authors declare that they have no competing

\section{Publisher's Note}

Veterinary World remains neutral with regard to jurisdictional claims in published map and institutional affiliation.

\section{References}

1. Helgen, K.M. and Flannery, T.F. (2004) Notes on the phalangerid marsupial genus Spilocuscus, with the description of a new species from Papua. J. Mammal., 85(5): 825-833.

2. Groves, C.P., Wilson, D.E. and Reeder, D.M., editors. (2005) Mammal Species of the World: A Taxonomic and Geographic Reference. $3^{\text {rd }}$ ed. Johns Hopkins University Press, Baltimore. p45-50.

3. Flannery, T.F. (1995) Mammals of New Guinea. Reed/ Australian Museum, Chatswood, NSW.

4. Leary, T., Singadan, R., Menzies, J., Helgen, K., Wright, D., Allison, A., Aplin, K. and Dickman, C. (2008) Spilocuscus maculatus. IUCN Red List of Threatened Species, Version 2008. International Union for Conservation of Nature, France.

5. Kunda, R.M., Handayani, N.S.N., Wijayanto, H. and
Widayanti, R. (2015) Study of genetic marker of cuscuses (Marsupialia: Phalangeridae) from Maluku and Papua based on Cytochrome b gene sequences. Pak. J. Biol. Sci., 19(3): 122-135.

6. Kunda, R.M. (2017) Kajian Penanda Genetik Gen Cytochrome B (CYT B) Dan Cytochrome Oxidase Sub-Unit III (COX III) Mitokondria Pada Kuskus (Phalangeridae). Disertasi, Program Studi Doktor Ilmu Sain Veteriner Fakultas Kedokteran Hewan. Yogyakarta, Universitas Gadjah Mada Yogyakarta.

7. Latinis, K. (1996) Hunting the cuscus in western Seram: The role of the phalanger in subsistence economies in Central Maluku. Cakalele, 7(1): 17-32.

8. Pattiselanno, F. (2007) Perburuan kuskus (Phalangeridae) oleh masyarakat napan di pulau ratewi, Nabire, Papua. Biodiversitas, 8(4): 274-278.

9. Ash, A., Elliot, A., Godfrey, S., Burmej, H., Abdad, M.Y., Northover, A., Wayne, A., Morris, K., Clode, P., Lymbery, A. and Thompson R.C.A. (2017) Morphological and molecular description of Ixodes woyliei n. sp. (Ixodidae) with consideration for co-extinction with its critically endangered marsupial host. Parasit and Vectors, 10(1): 1-16.

10. Greay, T.L., Oskam, C.L., Gofton, A.W., Rees, R.L., Ryan, U.M. and Irwin, P.J. (2016) A survey of ticks (Acari: Ixodidae) of companion animals in Australia. Parasit and Vectors, 9(1): 207.

11. Durden, L.A., Merker, S. and Beati, L. (2008) The tick fauna of Sulawesi, Indonesia (Acari: Ixodoidea: Argasidae and Ixodidae). Exp. Appl. Acarol., 45(1-2): 85-110.

12. Jackson, J. (1998) A new host record for Ixodes holocyclus Neumann and Ixodes cordifer Neumann (Acarina: Ixodidae) in Australia. Aust. J. Entomol., 37(2): 113-114.

13. Neumann, L.G. (1908) Notes sur les ixodidea. VII. Notes Leyden Museum, 30: 73-75

14. Anastos, G. (1950) The scutate ticks, or Ixodidae of Indonesia. Entomol. Am., 30(1): 1-144.

15. Roberts, F.H.S. (1955) Ixodes cordifer Neumann 1908 (Ixodes: Acarina). A description of the female and a redescription of the male (with two text-figures). Proc. R. Soc. Queensland., 66: 21-25.

16. Kwak, M.L., Beveridge, I., Koehler, A. F., Malipatil, Robin B. Gasser and Abdul Jabbar. (2017) Phylogenetic analysis of the Australasian paralysis ticks and their relatives (Ixodidae: Ixodes: Sternalixodes). Parasit. Vectors. 1-1.

17. Ahmad, Z., Anwar, Z., Adnan, M., Imtiaz, N., Rashid, H.U. and Gohar, F. (2019) Collection and prevalence of ticks in cattle and buffaloes from free-range management systems of Islamabad. J. Basic Appl. Zool., 80(1): 12.

18. Bush, A. O., Lafferty, K. D., Lotz, J. M., and Shostak, A. W. (1997) Parasitology meets ecology on its own terms: Margolis et al. revisited. J. Parasitol., 83, 575-58.

19. Barker, S.C., Walker, A.R. and Campelo, D. (2014) A list of the 70 species of Australian ticks; diagnostic guides to and species accounts of Ixodes holocyclus (paralysis tick), Ixodes cornuatus (southern paralysis tick) and Rhipicephalus australis (Australian cattle tick); and consideration of the. Int. J. Parasitol., 44(12): 941-953.

20. Schulze, P. (1935) Zur vergleichenden Anatomie der Zecken. Zeitschrift fur Morphologie und Okologie der Tiere, 30: 1 - 40 .

21. Estrada Pena (2015) Ticks as vectors: taxonomy, biology and ecology. Rev. Sci. Tech. Off. Int. Epiz., 34 (1): 53-65.

22. Viggers, K.L., Lindenmayer, D.B., Cunningham, R.B. and Donnelly, C.F. (1998) The effects of parasites on a wild population of the Mountain brushtail possum (Trichosurus caninus) in South-Eastern Australia. Int. J. Parasitol., 28(5): 747-755.

23. Latif, A.A. and Walker, A.R. (2004) An Introduction to the Biology and Control of Ticks in Africa, ICTTD-2 Project. p1-29. 